Pamiętnik Literacki 2020, 3, s. 101-117

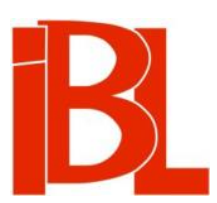

\title{
Mochnacki na nowo odkrywany. Dwa nieznane rękopisy listów.
}

Oprac. Agnieszka Markuszewska 


\title{
MOCHNACKI NA NOWO ODKRYWANY DWA NIEZNANE RĘKOPISY LISTÓW
}

\author{
Opracowała \\ AGNIESZKA MARKUSZEWSKA Uniwersytet Mikołaja Kopernika, Torun
}

Miesiąc przed śmiercią, w liście „do najdroższych rodziców” z 6 XI 1834 (opublikowanym jednak prawie 30 lat później, kiedy panowała moda na ogłaszanie różnego rodzaju „pism prywatnych”), schorowany Maurycy Mochnacki wyznał z goryczą:

\begin{abstract}
W emigracji wojna domowa trwa ciagle. Mnóstwo partii, rozjątrzenia coraz większe. Nie ma końca temu wszystkiemu. O co idzie? Co by to wszystko znaczyło? Na to odpowiedzieć trudno, i nigdy dostatecznie! Jest partia jedna, co się chce nazywać demokratami, druga jest partia Dwernickiego, który się prowadzi Bóg wie po jakiemu, trzecia jest partia dyplomatyczna, do czwartej należą ci wszyscy, którzy nie chcą o niczym wiedzieć i tylko w pokoju chcieliby się doczekać jakiejś pomyślnej pory. Te stronnictwa wojuja ze sobą w gazetach i pojedynkują się indywidualnie. Już mnie to wszystko znudziło do najwyższego stopnia ${ }^{1}$.
\end{abstract}

Przedśmiertny list romantycznego krytyka i polistopadowego emigranta, tak bardzo zaangażowanego w propolską działalność polityczną we Francji, to jedyna wypowiedź epistolarna Mochnackiego, której autentyczności nie jesteśmy w stanie dzisiaj zweryfikować. W Bibliotece Naukowej PAU i PAN w Krakowie wśród autografów zebranych przez znanego kolekcjonera Cypriana Walewskiego (t. 6, wiek XIX: Ł-O, sygn. 717, k. 651-652) oraz w prywatnym archiwum Marty Ławacz, spadkobierczyni bogatej spuścizny po Marii z Pagowskich Mochnackiej (matce krytyka), zachowały się rękopisy prawie wszystkich listów słanych przez Maurycego i Kamila Mochnackich do rodziny pozostawionej w Galicji. Po raz pierwszy ukazały się one w 1863 r. nakładem poznańskiego wydawcy Jana Konstantego Żupańskiego za zgodą matki autora jako jeden z tomów Dzieł Maurycego Mochnackiego $^{2}$. Wyjątkiem jest jednak zacytowana korespondencja. Jej autograf od wielu lat pozostaje nieznany: nie ma go ani w zbiorach krakowskich, ani w Bibliotece Polskiej w Paryżu, gdzie przeprowadzono specjalną kwerendę, ani w archiwum Mar-

1 M. M o chna cki, list do rodziców, z 6 XI 1834. W: Listy Maurycego Mochnackiego i brata jego Kamila, wysztych z wojskiem polskim do Francji $w$ roku 1831, pisane z Paryża, Metz i Avignon do rodziców swoich $w$ Galicji. Poznań 1863, s. 264. Dzieła. Wyd. jedynie prawne, ogłoszone z wiedzą matki autora. T. 1.

2 Na całość - oprócz listów - złożyły się następujące tomy: Powstanie narodu polskiego $w$ roku 1830 i 1831 (t. 2-3), Pisma rozmaite. Oddziat porewolucyjny (t. 4), O literaturze polskiej $w$ wieku dziewiętnastym (t. 5). 
ty Ławacz ${ }^{3}$. Autentyczność przywołanego fragmentu i zawartego w nim opisu emigracyjnych kłótni (o których jesienią $1834 \mathrm{w}$ istocie było głośno) ${ }^{4} \mathrm{z}$ łatwością można by zatem podać w wątpliwość. Nie dysponujemy wszak rękopisem.

Dla historyka badającego rozwój edytorstwa w XIX w. oraz dawne sposoby postępowania $z$ autografami tom $z$ korespondencją braci Mochnackich $z$ r. 1863 stanowi ciekawy materiał analityczny co najmniej z kilku powodów. Jest on szczególnym przykładem wydawniczej silva rerum, prezentującej nie tylko wypowiedzi epistolarne autorów wymienionych na karcie tytułowej, ale i wiele innych tekstów. Pod wspólną okładką opublikowano bowiem i rodzinna korespondencję braci Mochnackich, i listy ich bliskiego przyjaciela, towarzysza emigracyjnej niedoli, Michała Podczaszyńskiego, oraz wspomnienia Mochnackiej i jej liczne drobiazgowe komentarze objaśniające treść epistolografii. Pośród tych materiałów znalazły się także m.in. wycinki $z$ gazet francuskich (dotyczące chociażby koncertu fortepianowego Maurycego w Metzu), ustępy z polskich pism emigracyjnych, w tym artykuły Podczaszyńskiego, i listy osób postronnych, nie związanych z rodziną: Antoniego Walewskiego, majora Stefana Dembowskiego czy pani Turqui, „gospodyni domu, w którym mieszkał Maurycy" w Auxerre. Ten wyjątkowy zbiór jawi się jako swoista „hydra familijnych pamiątek”: wszak nad wspomnieniami szczęśliwymi przeważają tu wspomnienia raczej gorzkie. Można go też określić jako księge pamięci, sui generis album rodzinny mający przynieść ukojenie matczynemu sercu. To bowiem Mochnacka - co należy podkreślić - jest rzeczywistą autorką zbioru: dzięki jej staraniom listy synów stały się częścią większej całości, szerzej pomyślanego projektu wydawniczego. Tomu z r. 1863, do druku przygotowanego już jednak 20 lat wcześniej (1842), nie można więc traktować, jak już wspomniano, jako tradycyjnej edycji listów prywatnych. Pomieszczony w zbiorze materiał zmienia perspektywę badawcza - tom powinien być rozpatrywany w innych niż dotychczas kategoriach: jako edytorskie miscellanea o charakterze pomnikowo-wspomnieniowym, antologia tekstów dokumentująca ślady niezwykłego i tragicznego życia, poświadczonego nie tylko listowną opowieścią. Na tle ogłaszanych w drugiej połowie XIX w. tomów epistolarnych edycja Żupańskiego znacząco wyróżnia się zawartością i układem. Jak wiadomo, korespondencję wielkich poetów i pisarzy często wówczas poprzedzano apologetycznymi wstępami (casus listów Narcyzy Żmichowskiej) bądź opatrywano rozbudowanymi komentarzami wydawców tudzież obszernymi przypisami pełniącymi funkcje kreacyjne (przykład korespondencji Adama Mickiewicza i Zygmunta Krasińskiego). Tak dużą różnorodnością treści i formy, z jaką mamy do czynienia w przypadku listów braci Mochnackich, nie cechuje się jednak żaden XIX-wieczny zbiór epistolografii romantycznej ${ }^{5}$.

Omawiany tom jest interesujący jeszcze $z$ innego powodu, dla tych rozważań

3 Archiwum to opisał ostatnio M. Strzyżew ski w artykule Nieznane archiwum rodzinne Mochnackich („Sztuka Edycji” 2019, nr 1).

4 Zob. Z. W ój c i c ka, Dwaj przeciwnicy ideowi: Ludwik Nabielak i Maurycy Mochnacki. „Napis” t. 7 (2001). - S. Kal e mb ka, Tworzenie się organizacji i poszukiwanie dróg ideowych. W: Wielka Emigracja 1831-1863. Toruń 2003, s. 124-128.

5 Ówczesne zwyczaje związane z publikowaniem korespondencji opisała niedawno T. W in e k (Dziewiętnastowieczne pytania i deklaracje dotyczace wydawania listów. „Sztuka Edycji” 2019, nr 1). 
najistotniejszego. Otóż ukazuje on szereg zabiegów redakcyjnych służących wykreowaniu wizerunku nadawców korespondencji oraz odkrywa znamienne dla XIX stulecia strategie kreślenia (za pomocą różnego rodzaju rozwiązań i „technik” edytorskich) założonych $z$ góry „portretów biograficznych”. $Z$ tego typu działaniami mamy tu do czynienia na wielu płaszczyznach tekstowych. Określoną lekturę korespondencji narzucaja nie tylko noty, wspomnienia i komentarze matki polistopadowych emigrantów, starającej się usprawiedliwić wszystkie, nierzadko kontrowersyjne poczynania Maurycego Mochnackiego, upiększyć jego obraz tudzież sprostować plotki i potwarze rzucane przez lata pod adresem syna ${ }^{6}$. W tomie ważną funkcję pełnią też liczne odstępstwa od tekstu rękopiśmiennego, pozaautorskie modyfikacje zniekształcające zarówno styl, jak i sens pierwotnego zapisu, często niemal w całości zmieniające oryginalne brzmienie korespondencji. Autorką tych zmian, jak przekonująco dowodzi Mirosław Strzyżewski, także jest Mochnacka, w edycji wielokrotnie przyjmująca rolę nie tylko „cenzora rodzinnego”, ale i wspóltwórczyni „biografii pomnikowej” syna ${ }^{7}$. Prawie wszystkie jej działania (niewolne również od wielu tekstowych manipulacji oraz jawnego fałszowania przekazu źródłowego) zmierzają do jednego, ściśle określonego celu: wyidealizowania wizerunku syna, podkreślenia jego zalet i zdolności, wyeksponowania nietuzinkowego charakteru. O swoich intencjach Maria Mochnacka otwarcie pisała chociażby w nocie zamieszczonej pod ostatnim listem Maurycego, gdzie informowała czytelnika o najważniejszym aspekcie edycji: upublicznienie rodzinnej korespondencji miało przynieść „chlubę familii” i ukazać „przyszłym pokoleniom” cnoty i wzory godne naśladowania ${ }^{8}$. Tak więc, pragnąc np. zataić nieco wstydliwe fakty z życia Mochnackiego, skrupulatna „edytorka” usuwa niektóre fragmenty listów, pomija kontrowersyjne w jej opinii zdania i zastępuje je nowymi, subtelniejszymi passusami. Ingerując w treść korespondencji, ukrywa rodzinne scysje i niepowodzenia, nierzadko osłabia nadmierna emocjonalność wypowiedzi i skreśla niepochlebne komentarze na temat innych osób (casus nieudanego małżeństwa Klementyny Mochnackiej z Maciejem Grodzieckim i gróźb do niego kierowanych). Unika przy tym zniesławiania postaci powszechnie znanych i cenionych, np. Joachima Lelewela czy generała Karola Kniaziewicza, których Maurycy Mochnacki w listach bynajmniej nie oszczędzał. Autor Powstania narodu polskiego w roku 1830 i 1831 często formułował inwektywy pod ich adresem. Lelewela ironicznie nazywał „Himciem” i „intrygantem”, a Kniaziewicza - dla odmiany - „starym głupcem”. Upublicznienie tych nieobyczajnych treści mogłoby wywołać skandal i sprowokować ataki polityczne związane $z$ działalnościa emigracyjną Maurycego. Jak widać, Mochnackiej nie umyka żaden szczegół, z uwagą czyta ona wszystkie fragmenty korespondencji, czuwa nad wymową emocjonalną niemal każdego zdania. Teza

6 O XIX- i XX-wiecznej czarnej legendzie M. Mochnackiego zob. M. St r zy ż ew s ki, Legenda Mochnackiego. W zb.: Polska literatura wspótczesna wobec romantyzmu. Red. M. Łu k a s zu k, D. S ewe ry n. Lublin 2007.

7 Zob. artykuł M. Strzyż ew sk i e go Zmagania edytora korespondencji XIX-wiecznej. Orękopisach listów Antoniego Walewskiego i Stefana Dembowskiego z archiwum rodzinnego Mochnackich, zamieszczony w tym zeszycie „Pamiętnika Literackiego”.

$8 \quad$ Zob. Listy Maurycego Mochnackiego i brata jego Kamila [...], s. 289. 
o wpływie matki na ostateczny kształt wydania, o jej znaczących ingerencjach w treść i sens listów jest więc niepodważalna. Dowodzą tego szczegółowa analiza różnic między zachowanymi przekazami (tutaj zaprezentowana na przykładzie dwóch listów) oraz rekonstrukcja głównych założeń tomu, zawartych w materiałach uzupełniających zbiór: w notach Mochnackiej, w jej bogatych w szczegóły wspomnieniach i komentarzach.

Mimo wielości sposobów manipulowania zapisem oryginalnym cel wskazanych zabiegów pozostaje taki sam: ukazanie synów $\mathrm{z}$ jak najlepszej strony, niemal bez wad i niedoskonałości charakterologicznych. Wierność rękopisom schodzi na plan dalszy, a skrupulatność edytorska ustępuje miejsca wydawniczej mistyfikacji. W tomie z 1863 r. to nie Maurycy do nas przemawia - czytając zbiór, przyjmujemy perspektywę jego matki. Czy zatem cytowany na początku artykułu fragment listu jest wiarygodny i czy $z$ całkowita pewnością można go traktować jako wypowiedź Mochnackiego? Obawiam się, że nie. I to nie tylko dlatego, że mowa w nim o ówczesnej sytuacji politycznej, czyli o sprawach dyskusyjnych. Autentyczność przekazu podważa przede wszystkim lektura niedawno odnalezionych dwóch rękopisów listów (dotąd nie znanych), które - podobnie jak pozostała korespondencja - znacząco różnią się od wersji z pierwodruku. Co więcej, są to wypowiedzi bezpośrednio poprzedzające przedśmiertny list Mochnackiego. Tworzą $z$ nim swoistą epistolarną triadę, głównie ze względu na pokrewną tematykę i podobne emocje.

Różnic tekstowych między zapisem rękopiśmiennym a pierwodrukowym w dwóch przedstawianych tu listach jest 115 . W list z 25 VII 1834 zaingerowano 47 razy, a w korespondencje z 2 IX 1834 - 68. W trakcie porównywania przekazów odnotowywano jedynie zmiany najważniejsze. Gdyby kolaudacja tekstowa obejmowała odstępstwa od oryginału w zakresie ortografii, interpunkcji tudzież składni zdania, odmian byłoby znacznie więcej. W artykule ograniczono się do omówienia różnic najistotniejszych, nierzadko zmieniających sens oraz wymowę emocjonalną wielu listowych fragmentów. Szczegółowe zestawienie ingerencji pozaautorskich w odniesieniu do całej zachowanej korespondencji braci Mochnackich zostanie opublikowane w jej nowym wydaniu książkowym. Ponadto, jako że oba listy w wersji rękopiśmiennej i pierwodrukowej znacząco się od siebie różnią i mogą być de facto traktowane jako zapisy ze sobą nietożsame, zdecydowano się podać je tutaj w pełnym brzmieniu. Listowe wypowiedzi Maurycego Mochnackiego z 25 VII i 2 IX 1834, podkreślmy, były dotąd znane li tylko w wersji zniekształconej i tak też cytowano je w literaturze przedmiotu.

Najliczniejszą grupę różnic między przekazami tworzą tzw. poprawki stylistyczne, wprowadzane do listów zapewne po to, aby wyeliminować $z$ nich wszelkiego rodzaju niedoskonałości pierwotnego zapisu, zwłaszcza dość częste potknięcia pióra i usterki językowe. Ingerencja w tekst korespondencji dotyczy tu więc przede wszystkim zmiany szyku, dopisywania do wersji rękopiśmiennej nowych słów i zwrotów oraz zastępowania ich innymi, w opinii wydawców zapewne stosowniejszymi sformułowaniami. Znając edytorskie praktyki Jana Konstantego Żupańskiego, słynącego w środowisku księgarskim $\mathrm{z}$ rzetelności w opracowywaniu wydawanych materiałów (w szczególności o charakterze źródła) i wierności autografom (chlubnym przykładem są tu zwłaszcza Pisma rozmaite Joachima Lelewela z 1863 ro- 
ku $)^{9}$, i po szczegółowej analizie tekstowej można sformułować tezę, że to matka starała się wydoskonalić - w jej oczach niekiedy ułomny - zapis epistolarny. Wskutek wprowadzanej korekty i niepotrzebnych $\mathrm{z}$ dzisiejszej perspektywy retuszy stylistycznych wiele znamiennych dla Maurycego sformułowań zastąiono mniej wyrazistymi zwrotami i przyczyniono się tym samym do zatracenia charakterystycznego dla autora sposobu budowania wypowiedzi, formułowania myśli in statu nascendi. Warto przyjrzeć się tylko kilku wybranym poprawkom tego typu.

Zacznijmy od korekt najprostszych i - zdawałoby się - mało znaczących, które jedynie $\mathrm{z}$ pozoru nie zmieniają sensu wypowiedzi. W pierwszym $\mathrm{z}$ zachowanych listów (z 25 IX 1834) w miejscu takich rękopiśmiennych zapisów, jak: „bardzo dawno”, „te listy ze mną się minęły”, „blisko drukarni”, „bardzo jestem zatrudniony”, „drogi Papo”, „zaręczam kochanego Pape”, „Cóż ja”, „zaręczyć mógłbym”, „Oświadcza, każe oświadczać”, „Adres mój, kochany Papo, jest ten”, „cioci Zofii”, „miał ciagle kapelusz zdjęty”, w pierwodruku pojawiają się pokrewne im zwroty: „dawno bardzo”, „te listy się ze mna minęły”, „bardzo blisko drukarni”, „bardzo jestem zatrudnionym”, „kochany Papo”, „zaręczam kochanemu Papie”, „Co ja”, „zaręczyć bym mógł”, „Oświadcza i każe oświadczać”, „Adres mój, kochany Papo, jest ten sam”, „,mojej cioci Zofii”, „miał ciagle kapelusz zdjęty z głowy”. Mimo że te stylistyczne retusze nie przydają treści nowych znaczeń, to bez watpienia zniekształcają pierwotne brzmienie listu i modyfikują zapis, podważając jego autentyczność. Podobne „niewielkie” zmiany wprowadzono do wypowiedzi z 2 IX 1834. Czytamy w niej m.in.: „tegoż dnia”, „przychodzić do siebie”, „żyłem przez dni dwadzieścia”, „iż słabość już nie powróci”, „Wiadomości te”, „ale prawdziwie nie mam sił”, „Ale nieszczęścia tamtejsze nasze prywatne”, „bo za cóż”, „może być rozbita”, „Tak być musi”, „dom nasz jakie nieszczęście spotyka”, „i zaraz jak tylko się to stanie”, „rozszerzają niezgodę". W poznańskiej edycji korespondencji w tych miejscach odnajdujemy niby te same sformułowania i wyrażenia: „tego dnia”, „do siebie przychodzić”, „żyłem dni dwadzieścia”, ,że słabość nie powróci”, „Wiadomości”, „ale prawdziwie, że nie mam sił”, „Ale nieszczęścia tamtejsze prywatne nasze”, „bo i za cóż”, „może być rozbita”, „Tak musi być”, „dom nasz spotyka jakie nieszczęście”, „i zaraz jak się to stanie”, „rozszerzaja niezgody”.

Przestawianie szyku zdań, zmienianie liczby gramatycznej z pojedynczej na liczbę mnogą (i odwrotnie), uzupełnianie wersji autografowej o nowe słowa bądź usuwanie z niej zbędnych wyrażeń, czyli - najogólniej rzecz ujmując - narzucanie rękopisom odmiennego, nieautorskiego stylu wypowiedzi, to stałe cechy omawianego zbioru. Te swoiste zabiegi redakcyjne dotyczą niemal każdego fragmentu korespondencji, tak jakby Mochnacka uznała, że zachowane rękopisy nie nadają się do druku. Nie zawsze właściwy, „chropowaty” jej zdaniem sposób pisania syna należało bezwzględnie poprawić, skorygować wszystkie usterki stylistyczne i wyeliminować $z$ niego językowe skazy. Prawdopodobnie też $z$ tego powodu dbająca o każdy szczegół matka wyrugowała $z$ tkanki obu listów słowa niezdarne, pretensjonalne, mało wyszukane i w jej mniemaniu być może niezbyt literackie. Wyraz „zbierze” zastapiła np. słowem „uzbiera”, „wypatrywano” zamieniła na „upatrywano”, 
„postawić” na „przystawić”, ,pisała” na „opisała”, „niezmiernie trudna” na „bardzo trudna”, „wspomnę” na „przypomne”, a „nie dozwala” na „nie pozwala”. Pod jej piórem „budowa” stała się z kolei „nawą”, „generał” został archaizującym ,jenerałem”, „rewolucyjność” zaś niespodziewanie przekształciła się w „rewolucję”. Rękopiśmienne zdania: ,jest szczęśliwy, iż mu się zdarza okazja dopomożenia Polakowi”, ,jak żyję nigdy takich jak teraz nie odebrałem honorów, od wielkich i małych, od największych i najmniejszych” oraz „Pisząc historię, wszedłem, bo musiałem wejść, w stosunki z ludźmi, którzy rewolucję rządzili i zgubili - dawnymi nieprzyjaciółmi mymi”, po poprawkach wydawniczych przybrały następującą formę: ,jest szczęśliwy, że mu się nadarza pora dopomóc Polakowi”, ,jak żyje takich nie odebrałem honorów, od wielkich i małych, od największych do najmniejszych” i „Pisząc historia powstania, musiałem wejść w stosunki z ludźmi, którzy rewolucją rządzili i zgubili, z dawnymi nieprzyjaciółmi mymi”. Dopiero tak wygładzony tekst zdecydowano się upublicznić - udostępnić czytelnikom w okazałej edycji pomnikowej, poprawnej pod względem językowym, zgodnej $z$ wolą matki.

Korekty Mochnackiej często sięgały jednak dużo głębiej i wielokrotnie dotyczyły semantycznej warstwy zdania. W lipcowym liście syna pierwotne „ani słowa i żadnej odpowiedzi” z tylko sobie znanych powodów „edytorka” poprawiła chociażby na mniej wyraziste ,ani słowa odpowiedzi”, a wymowne „Upały niezmierne tego roku w Paryżu” zastapiła niejednoznacznym „Upały niezmierne tego roku”. Wydźwięk zdania został osłabiony także w przypadku informacji o wspólnym obiedzie u Adama Mickiewicza. W liście autor Powstania narodu polskiego w roku 1830 i 1831 napisał: „Jest on [tj. Mickiewicz] niezmiernie szczęśliwy i kontent, przynajmniej tak się mi wydawało, kiedym był u niego na obiedzie przed ślubem w Sèvres”. W wersji opublikowanej czytamy natomiast: „Jest on niezmiernie szczęśliwy i kontent, przynajmniej tak się mi wydawało, kiedym był u niego na obiedzie w Sèvres”. Usunięcie znamiennego dopowiedzenia "przed ślubem” skutkuje zatarciem chronologii i niemożnościa datowania wizyty Mochnackiego w Sèvres. Jest to o tyle ważne, że list Maurycego to jedyny zachowany przekaz źródłowy poświadczający owo spotkanie.

Jeszcze bardziej interesujących przykładów ingerowania w sens dostarcza list z 2 IX 1834, w którym - jak wspomniano - dokonano o wiele więcej modyfikacji treściowych. Opisując niedawno przebytą chorobę, Mochnacki zanotował: „Miałem kłucie w boku i bicie krwi do serca jak przeszłego roku. Widząc, że polscy doktorowie nie mogą mi dać rady, wezwałem pomocy jednego z najsławniejszych lekarzy paryskich, Pana Riccord”. W pierwodruku ten fragment brzmi inaczej: „miałem kłucie w boku i bicie krwi do serca jak przeszłego roku. Widząc, że polscy doktorowie nie mogą mi dać rady, wezwałem jednego z najsławniejszych lekarzy, pana Riccard”. Nie dość, że pan „Riccord” stał się panem „Riccard”, a zwrot „wezwałem pomocy” zamieniono na „wezwałem”, to jeszcze w druku wyraźnie zasugerowano, że lekarz Mochnackiego był sławny nie tylko w Paryżu, ale i w całej Francji, a może też nawet w innych krajach europejskich. W kontekście cytowanej wypowiedzi usunięcie tego ważnego dopowiedzenia wydaje się nieprzypadkowe. W trakcie lektury listu można bowiem odnieść wrażenie, że Mochnacki był postacią wyjątkową i znana w kręgach ówczesnej emigracji politycznej - do tego stopnia, że o jego zdrowie dbali zarówno polscy lekarze, jak i najznamienitsi „doktorowie” europejscy.

Mochnacka z pietyzmem dbała też o to, by częste odniesienia do rodziny i przy- 
jaciół domu zawsze świadczyły o czułości, serdeczności, szacunku i przywiązaniu. Z pragnieniem wyeksponowania zażyłych więzi familijnych, ujawniającym się w korespondencji wskutek licznych ingerencji, mamy do czynienia także w wypowiedzi z 2 IX 1834. Autor listu z przejęciem pisał wówczas (prawdopodobnie) o śmierci ciotki - „pani Lubinowej”, której „smutny koniec” miał „rozrzewnić” go „aż do płaczu”. Owszem, jak zaświadcza rękopis, wiadomość o ciotce była dla Mochnackiego przykra i w istocie doprowadziła go do łez. Nie użył on jednak wzmacniającego wypowiedź „aż”, a słowa „koniec” nie poprzedził sugestywnym przymiotnikiem „smutny”. Pierwotna wersja fragmentu jest zatem mniej emocjonalna niż wersja $\mathrm{z}$ pierwodruku i niewątpliwie wskazuje na inną temperaturę uczuć - choć nadal wysoka - względem tajemniczej „pani Lubinowej” (o ciotce Maurycego niestety nic nie wiemy). To bez watpienia matka rozpacza nad jej losem i to ona kreuje uczuciowa atmosferę tego epistolarnego ustępu.

Podobnie dzieje się we fragmencie, który odnosi się do wieloletniego przyjaciela domu - Jana Henryka Sagatyńskiego. Aby ukazać jego oddanie rodzinie Mochnackich i gotowość niesienia pomocy niezależnie od okoliczności i sytuacji, skrupulatna „edytorka” dokonała znaczącej ingerencji w treść wrześniowego listu. Pierwsze słowa oryginalnego zapisu: „Wiele razy dom nasz jakie nieszczęście spotyka, po tylekroć od młodości mojej spostrzegam około niego rękę przyjacielską kochanego i drogiego mojemu sercu Pana Jana Henryka!", zmodyfikowała następująco: „Wiele razy dom nasz jakie nieszczęście spotyka, po tylekroć od dzieciństwa mego spostrzegam...” $Z$ wprowadzonej zmiany wynika, że przyjaźń $z$ „panem Janem Henrykiem” trwała o wiele dłużej, niż zasugerował w liście Maurycy, i sięgała czasów nie „młodości”, ale „dzieciństwa” pierworodnego syna. Podkreślenie zasług Sagatyńskiego i jego szczególnego przywiązania do familii, jak widać, było dla Mochnackiej ważniejsze niż zachowanie pierwotnego brzmienia autografu. Zamiast sprostować pomyłkę w przypisie lub w komentarzu do tego fragmentu zdecydowała się ona samowolnie przekształcić zdanie i nie pozostawić żadnej wątpliwości co do życzliwości i dobrego serca przyjaciela, któremu razem z mężem tak wiele zawdzięczała.

Matka polistopadowych emigrantów ton i sens wypowiedzi potrafiła zmienić również w odniesieniu do samej siebie. W liście z 25 VII 1834 Mochnacki poskarżył się na brak korespondencji z Galicji i zanotował z nieskrywanym żalem: „Osobliwie Mama, Mama, która przedtem tak wiele i często do mnie pisywała, zapomniała zupełnie o jedynym dziecku swoim za granica". W odpowiedzi na to wyznanie i - co najważniejsze - chcąc nie tylko podkreślić przywiązanie do ukochanej matki, ale i osłabić zawarty w tym fragmencie zarzut, ,edytorka” zmodyfikowała to z pewnościa nieprzyjemne dla siebie zdanie i zastapiła je innym ustępem: „Osobliwie Mama, moja Mama! która przedtem tak wiele i często do mnie pisywała, zapomniała o jedynym dziecku swoim za granicą. Do listu dodała więc jakże emocjonalne wykrzyknienie „moja Mama!”, a dużo mówiące sformułowanie „zapomniała zupełnie” przekształciła w proste „zapomniała”. Ingerując w tekst, złagodziła zatem zawarte w wypowiedzi syna oskarżenie i podkreśliła jego zagubienie, samotność i tęsknotę za rodziną. W takim kontekście tym bardziej dziwia charakterystyczne dla obu omawianych listów zabiegi służące powściagnięciu ekspresji piszącego, gdy ten zwracał się do innych członków familii - zwłaszcza do ojca, Bazylego. Mochnacki 
robił to zazwyczaj za pomocą słów „kochany” lub „drogi Papo”. W pierwodruku zwroty te wielokrotnie występują w postaci zwykłego, skróconego „Papo”. Poznańską edycję znamionuje jednak w tym zakresie duża niekonsekwencja (o trudnej do ustalenia proweniencji). W niektórych listach zwroty tego typu Mochnacka traktuje bowiem jako zbędny uczuciowy naddatek, w innych - dodaje je bez umiaru i wprowadza tam, gdzie nie sa potrzebne.

Niestety, w przypadku wielu modyfikacji zmieniających sens pierwotnego brzmienia listów trudno jednoznacznie stwierdzić, co było ich przyczyną i celem. Analizując niektóre fragmenty korespondencji, trudno rozstrzygnąc, czy korygującej treść listów matce chodziło wyłącznie o wygładzenie stylu syna. Być może kierowała się ona czymś jeszcze. Dlaczego zdania z wrześniowej wypowiedzi, takie jak: „Mnie nic innego nie pozostaje, tylko siedzieć w Paryżu, pracować i zarabiać sobie na życie i dobre imię u ludzi”, „co jednak żadnego wpływu na dzieło moje nie ma, bo ja pisze [wyraz nieczytelny, ale z pewnością inny niż w pierwodruku - A. M.]" czy „Ci ludzie (licząc w to całą partię, która się w Paryżu znajduje) zachowali więcej zimnej krwi, taktu i sumienia jak rewolucjoniści”, w pierwodruku mają odmienną postać? Czy ich nowe wersje: „Mnie, jako takiemu, nic innego nie pozostaje, jak tylko siedzieć w Paryżu, pracować i zarabiać sobie na dobre życie i dobre imię u ludzi”, „co jednak żadnego wpływu na dzieło moje nie ma, mieć nie będzie, ani może, bo ja piszę bezinteresownie” i „Ci ludzie, licząc w to cała partię, która się w Paryżu znajduje, zachowali dziś więcej zimnej krwi, taktu, zdrowego rozsądku i sumienia jak rewolucjoniści", naprawdę są lepsze, wyrazistsze, ciekawsze? Czemu służyło to dopisywanie wyrazów (,jako takiemu”, „dobre życie”, „mieć nie będzie, ani może”, „zdrowego rozsądku”), przestawianie słów, zmienianie szyku zdań? Czy po wprowadzeniu tych poprawek wizerunek piszacego był bliższy wyobrażeniom matki i rodziny pozostawionej w kraju? Czy spełniał ich oczekiwania oraz dawał nadzieję na szybką rehabilitację ukochanego syna i brata w oczach współczesnych? Mochnacki, jaki wyłania się $z$ kart pierwodruku, jest bez wątpienia postacią subtelniejszą, charakterologicznie stonowaną, posługującą się piórem w sposób rozważny, dojrzalszy, niekiedy nawet powściagliwy. Autor listów w edycji poznańskiej to jednak tylko namiastka prawdziwego Maurycego - to człowiek odarty z wad i ułomności, pisarz uładzony, przepuszczony przez pryzmat matczynych pragnień i lęków. Rzeczywisty podmiot epistolarny jest natomiast postacią znacznie bardziej skomplikowaną i niejednoznaczną. Publikowane tu listy stanowią więc pierwszy krok w odzyskiwaniu prawdziwego wizerunku Mochnackiego ${ }^{10}$.

Zastosowane w obu listach procedury modernizacyjne nie wykraczaja poza zasady przyjęte w wydaniach popularnonaukowych (typu B); zachowano oryginalne formy

10 Warto zauważyć, że w porównaniu z innymi listami M. Mochnackiego zamieszczonymi w zbiorze z 1863 r. w omawianych wypowiedziach epistolarnych Maria z Pagowskich prawie w ogóle nie poprawiała listów syna pod względem wymowy politycznej. Za jedyną ingerencję tego typu można uznać przekształcenie zdania „Przyjechał tu i nasz kochanek książę, minister L....”, które odnosiło się do K. Druckiego-Lubeckiego. W pierwodruku czytamy: „Przyjechał tu i nasz kochanek, minister Lubecki..." Również dodanie do cytowanego wcześniej listowego fragmentu wyrażenia „Zdrowy rozsądek” (ustęp ten, przypomnijmy, dotyczył zwolenników księcia A. J. Czartoryskiego) mogło wiązać się ze względami politycznymi. 
językowe autora, które odtworzono na podstawie rękopisu. Ortografię przystosowano więc do obowiązującej dziś normy językowej. Uwspółcześniono formy typu: „xiążę”, „wyexpediować” (po modernizacji: „książę”, „wyekspediować”), a także usunięto występujące w niektórych wyrazach podwójne spółgłoski: „adress” $\rightarrow$ „adres”, „interessa” $\rightarrow$ „interesa”, „klassa” $\rightarrow$ „klasa”. Zmodernizowano pisownię „i” (częstsza) oraz „y” w pozycji joty: „korespondencjia” $\rightarrow$ „korespondencja”, „historjia” $\rightarrow$ „historia”, „okazjia” $\rightarrow$ „okazja”, „emigracjia” $\rightarrow$ „emigracja”, „dyeta” $\rightarrow$ „dieta”, podobnie jak pisownię nosówek, mimo że sugerowany w autografie zanik nosowości może stanowić cechę swoistą w zakresie artykulacji. Przyjęto współczesne końcówki w bierniku rzeczowników żeńskich zakończonych na „-a”” („protekcjią” $\rightarrow$,protekcje”, ,amnestija” $\rightarrow$,amnestie””, „instrukcjia” $\rightarrow$,instrukcje””) oraz w narzędniku i miejscowniku przymiotników i zaimków rodzaju nijakiego liczby pojedynczej i liczby mnogiej odmiany niemęskoosobowej zakończonych na „-em”, ,-emi” („znośniejszem” $\rightarrow$ „Znośniejszym”, „o niczem” $\rightarrow$ „o niczym”, „memi” $\rightarrow$ „mymi”, „rossyjskiem” $\rightarrow$ „rosyjskim”).

Odstępstwem od pełnej modernizacji pisowni w zakresie fonetyczno-fleksyjnym są pozostawione w postaci oryginalnej te formy wyrazowe, co do których zachodzi duże prawdopodobieństwo, że stanowią one obraz cech właściwych językowi autora. Nie zmieniano więc takich zapisów, jak: „w Polszcze”, „leżyć” (w znaczeniu: „leżeć”) czy „pomyślić”. Zachowano również pierwotne (niepoprawne) brzmienie nazw własnych, m.in. charakterystyczną dla obu listów nazwę "Champs-Elisées”. Ujednolicono pisownię wielkiej litery w zwrotach grzecznościowych: „Papa”, „Mama”, „Rodzice”, „Pan”, „Pani”. Usunięto za to występującą w autografie wielką literę w nazwach miesięcy i w słowach, które zaczynają się litera „K”, a nie są nazwami własnymi, wyrazami nacechowanymi ekspresywnie lub formami grzecznościowymi. Nie ujednolicano zapisu liczebników i pozostawiono je w wersji oryginalnej, mimo że zapisy te odbiegają niekiedy od współcześnie przyjętych zasad.

W dużym zakresie zmodernizowano interpunkcję (chodzi zwłaszcza o imiesłowowe równoważniki zdania). Usunięto nadmiar dwukropków i średników występujących w funkcji kropki, zostawiając je tylko tam, gdzie jest to uzasadnione. Pauzy poprzedzone kropka, służące wprowadzeniu nowej myśli, potraktowano jako początki akapitów. Dla zwiększenia przejrzystości i czytelności tekstu akapity zdecydowano się również wprowadzić w obszernych passusach pisanych bez graficznego podziału na fragmenty.

Występujące w listach nawiasy okragłe ( ) pochodzą od Mochnackiego. Nawiasy ostrokątne ' ' wprowadzono dla oznaczenia skreśleń, nawiasy ' ' wskazują natomiast na tekst przez autora nadpisany. Nawiasy kwadratowe [ ] są używane w celu oznaczenia koniektur i emendacji oraz służą rozwinięciu skrótów. Tytuły, zgodnie z dzisiejszym zwyczajem, zapisano kursywą. Drukiem rozstrzelonym wyróżniono zaś miejsca w autografie podkreślone linią ciągłą. 
Paryż, dnia 25 lipca 1834

Champs-Elisées, Rond-Point $n^{\circ} 4$

Najdroższy Papo!

Nie wiem, jaki los ten list, 'który‘ piszę, spotka, bo już bardzo dawno od kochanych Rodziców, od pół roku przeszło, nie mam ani słowa i żadnej odpowiedzi na listów kilka, które pisałem! Tylko z Drezna przysłano mi karteczkę od Mamy, a potem w czerwcu widziałem słów kilka od Papy w liście nie do mnie, ale do Ludwika N...... ${ }^{1}$, gdzie Papa czynisz wzmiankę o pieniądzach (500 fr[anków]), które odebrałem, i o liście, który był adresowany do $\mathrm{Marly}^{2}$, gdzie go jednak, szukając na pobliskich pocztamtach $^{3}$ w St. Germain ${ }^{4}$ i Louvelance ${ }^{5}$, nie znalazłem, ani na wielkiej poczcie w Paryżu ${ }^{6}$. Być może, iż zmiany pomieszkania mojego są tego przyczyną, że na pocztach pośrednich ulicznych te listy ze mną się minęły. Ale mnie niepokoją listy moje, które pisałem pod dawnym adresem: czy doszły? Czy coś nie dzieje się z nimi po drogach? Czy w ogólności korespondencja z Francją nie doznaje tam utrudzenia? Bo bardzo wiele osób skarży się tu na to. Powtórzę więc w treści, com parę razy w listach moich nadmienił.

Po napisaniu ostatniego listu mojego 'do Papy` przeniosłem się z M a rly-1e - Ro i do Paryża na rok nowy dla druku drugiego tomu dzieła mojego ${ }^{7}$ i stanąem na ulicy Dauphine ${ }^{8}$, Hôtel Da u phine, blisko drukarni. Tam mieszkałem aż do '30-go maja, to jest do czasu, w którym się skończył druk tomu drugiego mojej historii. Stamtąd przeniosłem się na Champs-Elisées, gdzie teraz mieszkam i mieszkać ciagle zamierzam. Upały niezmierne tego roku w Paryżu zmusiły mnie szukać w tym miejscu lepszego powietrza jak na ulicy Dauphine. Mieszkam między drzewami, cokolwiek dalej od miasta, ale taniej i zdrowiej. Upały i ciagła praca sprawiły, że dla krwi łatwej do zapalenia się i uderzenia w głowę musiano mi parę razy stawiać pijawki, tak że przez kilka tygodni byłem 'znowu słaby, nie tak jak przeszłego roku przed śmiercią Kamila ${ }^{9}$, zawsze jednak niebezpiecznie. Teraz po długiej diecie i lekarstwach znowu, chwała Bogu, mam się lepiej, ale czuję, że nie to jest to zdrowie, które miałem dawniej. W ogólności, skutki rany spod Ostrołęki ${ }^{10}$ dają mi się czuć ustawnie przy ziewaniu, które całą kolumnę pacierzową wstrząsa, przy kichaniu i śmianiu się. Doktorowie nie mogą na to 'nic poradzić, bo nawet kapiele nie pomagają, których wziąłem 60 i kilka bez skutku. Opisawszy stan mojego zdrowia, proszę kochanego Papy, żeby mi o swoim doniósł oraz o zdrowiu kochanej Mamy, cioci Zofii ${ }^{11}$, kochanej Olimpki ${ }^{12}$ i Tymoleona ${ }^{13}$. Mnie teraz, kiedy sobie wspomnę, że miałem tyle braci i sióstr ${ }^{14}$, tyle familii, że mieszkałem w domu drogich moich Rodziców, zdaje się, że to był sen tylko, a każda taka myśl głębokim smutkiem rozdziera duszę moją. Osobliwie po śmierci Kamila już nie ma dla mnie żadnej pociechy za granica i tylko to jedno, że bardzo jestem zatrudniony, to jedno życie moje czyni cokolwiek znośniejszym. Mógłbym [tu] jeszcze dodać, że tylko nadzieja, że się tu z Papą obaczę ${ }^{15}$, dodaje mi sił i ducha, bo z resztą nie byłoby warto żyć na tym świecie.

Tom trze ci Powstania, równie gruby jak dwa pierwsze ( $30^{\text {ci }}$ arkuszy), będzie skończony w przyszłym miesiącu, lecz historii nie kończy. Będzie więc i tom $4^{\text {ty: }}$ 
ogromne dzieło! Trzy razy większe, jak myślałem, bo wszystkiego będzie 110-11[5] arkuszy. Pokazuje się więc, drogi Papo, że miałem rację wejść w entrepryzę $z$ Chełmickim ${ }^{16}$; bo skądże byśmy inaczej byli wzięli tych 8-9,000 franków, jakich cały nakład wymaga? Prenumeratorom moim w prospekcie posłanym do Galicji ${ }^{17}$ obiecałem arkuszy 40, tomów 2; lecz teraz już jest wydrukowanych arkuszy $64 \mathrm{w}$ tych dwóch tomach, które wyszły, a jeszcze dwa tomy dostaną. Więc za 15 franków, które zapłacili, nic taniej nabyć nie mogli. Tę rzecz warto rozważyć, kochany Papo! Tom pierwszy, drugi i trzeci razem wyekspediuję do Papy w liczbie 300 egzemplarzy. Nastąpi to ku końcowi sierpnia, nastąpi z niesłychaną trudnością, bo transport taki to rzecz niemała. Te trzy tomy każe tedy kochany Papa rozdawać moim prenumeratorom. Ale inna rzecz będzie $z$ tomem $4^{y m}$; za ten tom, gdy przyjdzie, będa musieli prenumeratorowie moi zapłacić osobno; będą musieli dopłacić po 10 franków. A to wszystko, co się z tej dopłaty zbierze, będzie własnością kochanego Papy. Będzie to fundusz na drogę do Paryża, bo ta idea głęboko leży w mojej duszy. Choćby nawet Papa nie chciał długo zabawić w Paryżu, to przecież z sobą widzieć się musimy. Całe moje szczęście od tego zależy.

Praca, która podjąłem, jest wprawdzie wielka, ale poprawia ona niezmiernie i interesa, i położenia moje. Jakkolwiek pójdą interesa ogólne kraju, zaręczam kochanego Papę, że autorowi historii powstania źle nie będzie. Biorąc miarę z wrażenia, jakie to dzieło czyni w emigracji ${ }^{18}$, łatwo moge przeczuć skutek, jaki w kraju sprawi. Tu przyszedłem do respektu u ludzi, tak iż powiedzieć mogę, że teraz dopiero coś mogę, i niemal z pewnością zaręczyć mógłbym, że droga, którą sobie otwieram, która sobie otworzyłem, zaprowadzi mnie daleko. Wszak to, kochany Papo, jak żyję, nigdy takich jak teraz nie odebrałem honorów, od wielkich i małych, od największych i najmniejszych. Nie piszę o tym dlatego, żeby się chwalić, ale iż wiem, że to kochanego Papę cieszyć będzie, że mu tu wstydu za granicą nie robię. Interes więc tej historii nie jest zły wcale. Mam jeszcze wiele do zrobienia, lecz niewątpliwie koło listopada wszystko będzie i ukończone, i posłane do Papy. Michał ${ }^{19}$ jest bardzo słaby - słabość ta sama co Kamila. Wyjedzie on 'pewnieı na południe. Nie daj Boże, aby po to samo co Kamil. Stetryczał i zrobił się wielkim, nerwowym fantastykiem, co przy kaszlu jego i krótkim oddechu nic mi dobrego nie zwiastuje.

Adres mój, kochany Papo, jest ten: Maurice Camille, Champs-Elisé e s, R ond-Point $n^{\circ} 4$. Pomieszkanie moje jest śliczne i tanie-między drzewami w alei, która do bariery É to il $\mathrm{e}^{20}$ prowadzi. Codziennie widzę z okna kilka tysięcy pojazdów i kilkanaście tysięcy ludzi. Teraz w czasie lipcowej uroczystości ${ }^{21}$ jest to hałas i gwar niepodobny do opisania. Francuzi zdają się być kontenci, ale to pozór tylko. Głową tego rządu nie chciałbym być za nic w świecie. Lecz mniejsza o to. Adam Mickiewicz ożenił się tu z panną Szymanowską ${ }^{22}$, córką pani Szymanowskiej, sławnej fortepianistki ${ }^{23}$. Jest on niezmiernie szczęśliwy i kontent, przynajmniej tak się mi wydawało, kiedym był u niego na obiedzie przed ślubem ${ }^{24}$ w Sèv re s ${ }^{25}$; teraz mieszka $z$ żoną w Paryżu. On nic nie ma i ona nic nie ma; ale ona ma za sobą protekcję klasy ${ }^{26}$, któr[a] kontenta, że posiadła p o e tę, nie da mu uczuć biedy i składać się na niego będzie. Przyjechał tu i nasz kochanek książę, minister L...... ${ }^{27}$. Oświadcza, każe oświadczać, że ma najsurowszy zakaz od cara widzenia się z kimkolwiek w emigracji; ale to pozór tylko, aby pod gwarancja tajemnicy ze wszystkimi się mógł widzieć. T[o] misja pod tytułem likwidacji sum 
należnych Polszcze, likwidacji, o której ani chca wiedzieć Francuzi, jest to zamach na nas. Krok ten kompromituje cara, bo dowodzi, że mu niezmiernie wiele na emigracji zależy. Oczekuję z najwyższą niecierpliwością listu od Papy - listu najobszerniejszego, jak tylko być może, zapełnionego szczegółami o zdrowiu Rodziców moich i całej familii, listu pożądanego dla mnie, tak jak niczego goręcej nie pragnąłem. Osobliwie Mama, Mama, która przedtem tak wiele i często do mnie pisywała, zapomniała zupełnie o jedynym dziecku swoim za granica. Ciotka Zosia, która także pierwej, kiedy Kamil żył, pisała, teraz już nic pisać nie chce. Cóż ja z tego wszystkiego mam wnosić? Chyba to, że źle jest być z daleka od domu, bo niezmiernie idziemy w zapomnienie. Co się z Klimką ${ }^{28}$ dzieje? Także nic nie wiem. Czy już poszła za mą̇̇?

Wczoraj widziałem Ludwika Filipa ${ }^{29}$ na qu a i ${ }^{30}$ wśród ogromnego zbioru ludzi; kłaniał się wszystkim, albo raczej miał ciągle kapelusz zdjęty - a sprawił sobie perukę czarna, bo mu w troskach monarchii lipcowej wszystkie włosy powyłaziły. Synowie jego ${ }^{31}$ i on nic teraz nie robią, tylko ciagle na koniach objeżdżają Paryż i kłaniają się pospólstwu, jakby mu dziękować chcieli za koronę. W kwietniu kazali strzelać do tego pospólstwa ${ }^{32}$. Zabijali na ulicach kobiety i dzieci nawet; ostatnie na własne oczy widziałem.

Całuję rączki i nóżki kochanego Papy.

\section{Maurycy}

Dwie karty formatu $18,6 \times 24,4 \mathrm{~cm}$, zapisane obustronnie w układzie jednokolumnowym. Pismo czytelne i wyraziste, bez skreśleń, ale z licznymi nadpisaniami. Brak koperty z informacją o odbiorcy.

1 Ludwik Na bi e la k (1804-1883), powstaniec listopadowy, jeden z uczestników ataku na Belweder, współzałożyciel Towarzystwa Patriotycznego, działacz Towarzystwa Demokratycznego Polskiego w Paryżu. Do roku 1834 utrzymywał z Mochnackimi zażyłe stosunki. Tuż przed śmiercią Maurycego, 29 XI 1834, w Paryżu ukazała się publiczna odezwa Nabielaka, w której wystapił przeciwko tzw. pismom auxerskim najprawdopodobniej autorstwa Mochnackiego.

2 Marly-le-Roi - podparyska miejscowość, w której Mochnacki z powodów zdrowotnych przebywał od drugiej połowy lipca 1833.

3 Pocztamt (z ros.) - daw., biuro zarządu poczty, poczta.

4 Saint-Germain-en-Laye - miejscowość położona na zachód od Paryża (nieopodal Marly-le-Roi), w której Mochnacki często wówczas bywał.

5 Mowa najprawdopodobniej o miejscowości Louveciennes, znajdującej się na wschód od Marly-le-Roi.

6 Autor listu ma na myśli zapewne główną pocztę paryską (hôtel des Postes), usytuowaną w nie istniejącym dziś pałacu Armenonville (przy dawnej rue Plâtrière).

7 Dwa pierwsze tomy Powstania narodu polskiego w roku 1830 i 1831 ukazały się wiosną 1834 nakładem paryskiej firmy księgarskiej P. Baudouina (jej siedziba znajdowała się przy rue Mignon $\mathrm{n}^{\circ}$ 2). Mochnacki planował napisać $\mathrm{w}$ sumie cztery części historii powstania listopadowego: tom trzeci miał być zatytułowany Kampania, a czwarty - Koniec rewolucji. Rue Dauphine - ulica w szóstej dzielnicy Paryża.

9 Kamil Mochnacki (ur. 1806), brat Maurycego, zmarł na gruźlicę 17 VIII 1833 w Hyères na południu Francji (dzisiaj miejsce jego pochówku nie jest znane).

10 W bitwie pod Ostrołęką (26 V 1831) Mochnacki odniósł ciężkie rany. Za obronę armat został odznaczony krzyżem Virtuti Militari.

11 Zofia Pagowska, siostra Marii Mochnackiej.

12 Olimpia Mochnacka (po mężu: Go r ecka), młodsza siostra Maurycego.

13 Tymoleon Mochnacki (1811-1889), najmłodszy syn Bazylego i Marii Mochnackich, uczestnik powstania listopadowego, w 1831 r. uzyskał stopień porucznika, następnie gospodarzył w dobrach Tyśmieniczany i Zabereże. 

konstytucyjnych i likwidowaniem republikańskich stowarzyszeń, a także coraz bardziej widocznymi nierównościami społecznymi.

Drugą młodszą siostrą Mochnackiego była Klementyna (ok. 1810 - ?).

Mochnacki pragną sprowadzić ojca do Francji, o czym informował zarówno w pierwszym, jak i w ostatnim liście pisanym na emigracji (z 14 I 1832 i z 6 XI 1834).

Wincenty Chełmicki (1786-1846), poseł przasnyski, pierwszy wydawca Powstania narodu polskiego $w$ roku 1830 i 1831. We wrześniu i w październiku 1834 na łamach „Kroniki Emigracji Polskiej” oraz „Tygodnika Emigracji Polskiej” Mochnacki i Chełmicki stoczyli głośną polemikę. Autor dzieła nie chciał zgodzić się na powtórne wydanie tomów, uzupełnionych przez Chełmickiego „wiadomościami o nieznanych faktach” dotyczącymi powstania, nadsyłanymi przez innych polistopadowych emigrantów.

Mochnacki zabiegał o druk swojego dzieła także u lwowskiego księgarza Jana Mili k ow s ki e go (1781-1866), z którym spotkał się w tej sprawie w czerwcu 1833. Miał nadzieję, że stanie się on głównym nakładcą i dystrybutorem Powstania [...] w Galicji. Plan ten nie został jednak zrealizowany. Mimo zapewnień Maurycego o pozytywnym odbiorze Powstania narodu polskiego $w$ roku 1830 i 1831 dzieło to nie zostało dobrze przyjęte w kręgach emigracji polskiej i doczekało się tylko kilku (zresztą negatywnych) recenzji na łamach ówczesnej prasy.

Michał Po d c za s zy ń s ki (1800-1835), wydawca „Pamiętnika Emigracji Polskiej”, bliski przyjaciel Maurycego i Kamila Mochnackich; zmarł na gruźlicę 4 VII 1835 w Paryżu.

Barrière Étoile - rogatka we wschodniej części placu Étoile, dzisiaj już nie istniejąca.

Chodzi o uroczystości upamiętniające rewolucję lipcową (1830).

Ślub Adama Mickiewicza z Celiną S zy m a n o w s ką (1812-1855) odbył się 22 VII 1834 w paryskim kościele Saint-Louis d'Antin.

O grze Marii Szy man ow ski j (1789-1831) Mochnacki pisał już w okresie warszawskim w artykule Jeszcze kilka słów o koncercie p. Szymanowskiej z powodu jej recenzentów („Gazeta Polska” 1827, $\mathrm{nr} 44, \mathrm{z} 13$ II).

List Mochnackiego jest jedynym źródłem poświadczającym to spotkanie.

Wiosną 1834 Mickiewicz przez krótki czas mieszkał w Sèvres, podparyskiej miejscowości położonej nad Sekwaną.

Mochnacki pisze tu najprawdopodobniej o frankistach (z którymi związani byli Wołowscy, rodzina Marii Szymanowskiej).

Ksawery Dru ck i - Lu b e c k i (1779-1846), minister skarbu Królestwa Kongresowego, założyciel Banku Polskiego (1828), przeciwnik powstania listopadowego. Do Paryża przyjechał 14 VII 1834 i w imieniu cara Mikołaja I (1796-1855) dopominał się o zwrot pieniędzy przekazanych Francji przez Księstwo Warszawskie (na potrzeby armii).

Klimką Mochnacki nazywał swoją młodszą siostrę Klementynę.

Ludwik Filip I (1773-1850), monarcha Francji w latach 1830-1848.

quai (fr.) - bulwar nadbrzeżny.

Ludwik Filip I i jego żona, Maria Amelia Burbon-Sycylijska (1782-1866), doczekali się licznego potomstwa: czterech córek i sześciu synów.

Mowa o paryskich zamieszkach z kwietnia 1834, wywołanych ograniczaniem przez króla wolności

2

Paryż, Champs-Elisées, Rond-Point n ${ }^{\circ} 4$ Dnia 2 września 1834

\section{Szanowni i najdrożsi Rodzice!}

List kochanych Rodziców ız 13 sierp[nia]` odebrałem dnia 28 sierpnia; chciałem zaraz tegoż dnia odpisać, ale nie miałem sił, bo to właśnie było w czasie najmocniejszej słabości mojej, która mnie od maja trapiła. Lecz teraz zaczynam $z$ tej nowej recydywy ${ }^{1}$ zupełnie przychodzić do siebie. Historia tej nowej epoki mojej słabości 
jest taka. $Z$ dnia $3^{\text {go }}$ na $4^{\text {go }}$ sierpnia dostałem gwałtownej goraczki. Miałem kłucie w boku i bicie krwi do serca jak przeszłego roku² ${ }^{2}$. Widząc, że polscy doktorowie nie mogą mi dać rady, wezwałem pomocy jednego z najsławniejszych lekarzy paryskich, Pana Riccord ${ }^{3}$, który natychmiast przybył i oświadczył, że mnie wykuruje bez żadnej zapłaty i że jest szczęśliwy, iż mu się zdarza okazja dopomożenia Polakowi. Kazał on mi postawić 100 pijawek we trzech dniach, leżyć w łóżku, a jeść tylko pół funta winogron na dzień i pić filiżankę lekkiego bulionu. Tym sposobem żyłem przez dni dwadzieścia, nie ruszając się z łóżka i nie biorąc żadnej medycyny ${ }^{4}$ wewnątrz. Po dni[ach] 20 nowe pijawki, ale już tylko 30, i ta sama dieta. Nareszcie słabość złamała się, wtenczas właśnie, kiedy przyszedł list kochanego Papy - list, od którego nawet zdrowemu zupełnie człowiekowi można było zachorować, tak jest smutny i rozdzierający duszę. Dzisiaj, to jest drugiego września, tak się mam dobrze z łaski nieocenionego P[ana] Riccord, że mogę wstać, pisać, co większa, być pewnym, iż słabość już nie powróci. Na nowo więc odczytałem list kochanych Rodziców. Wiadomości te zrobiły na mnie nadzwyczajne wrażenie. Cóż to za upór losu! Co za nieprzewidziane nieszczęścia! Scena $z$ Tymoleonem ${ }^{5}$ najdotkliwiej mnie obeszła, a koniec pani Lubinowej ${ }^{6}$ rozrzewnił do płaczu. Wszystko to jest tragiczne i głęboko mnie porusza! Ale nieszczęścia tamtejsze nasze prywatne przypadają w porę tak nieszczęsną dla emigracji w ogólności, że nie wiem, czy to jest skutek słabości mojej, ale prawdziwie nie mam sił do wyrażenia, co czuję. Nie wiem nawet, co mnie mocniej boli, czy domowa niedola, czy klęski, które tu nam zagrażaja. Król w zmowie $z$ Moskwa ${ }^{7}$, o niczym bardziej nie myśli, jak żeby przymusić Polaków do powrotu. Pozzo di Borgo ${ }^{8}$ odebrał przed dniami 15 instrukcję następującą: „Ktobykolwiek zgłosił się do ambasady po amnestię, oświadczyć mu, że jeżeli jest żołnierzem wojskowym, będzie musiał odsłużyć lat 15 w wojsku rosyjskim w głębi Rosji, a jeżeli jest cywilnym, to odsiedzi lat $15 \mathrm{w}$ guberni permskiej albo w perejasławskiej9!" Czy dasz Papa temu wiarę? Oto zaraz $200 \mathrm{z}$ emigracji przystało na tę kondycję. $Z$ tego można wziąc miarę, jak jest okropny dla Polaków pobyt we Francji. Książę L. ${ }^{10}$ jest tu posłany na rekonesans. Jego działanie tajemne może pociagnąc za sobą ruinę emigracji. Nie widuje się on $z$ nikim i nie chce się $z$ nikim widzieć. On tu jest posłany po to, żeby wyjednał w rządzie uchylenie żołdu na rok jeszcze (o s ta t ni) zapewnionego Polakom. Po czym naturalnie cała emigracja będzie musiała przyjąć amnestię, jaką się będzie podobało dać carowi. Zważyć trzeba, że gdyby emigracja nawet po uchyleniu żołdu nie chciała wracać do kraju, rząd na mocy prawa z 21 kwietnia $^{11}$ ma moc wyrugować emigracje przemoca. Wszakże amnestia jest tylko dla emigracji w ogólności, bo co do 200 osób (między którymi i ja jestem), skazanych już na śmierć, dla tych nigdy nie będzie żadnej amnestii. Te osoby muszą albo umrzeć za granica - albo wrócą do kraju kiedyś z bronią - ale tylko z bronią, inaczej nie. Emigracja cała jest zakłócona, zaszargana, rozerwana - nie masz 10 Polaków, którzy by byli zgodni ze sobą - jest to wojna domowa najokropniejsza, o jakiej tylko pomyślić można. Generałowie bez powagi, szulery, umykają z Paryża, żeby ich za długi w St. Pelagie ${ }^{12}$ nie osadzono, pełno duchów i pieniędzy moskiewskich po zakładach, gazeciarze pod pozorem rewolucyjności i patriotyzmu rozszerzają niezgodę za pieniądze moskiewskie, bo za cóż mogliby drukować tyle bezeceństw, tyle potwarzy, których tu nikt ani chce, ani może kupować? Zawrót głowy opanował większość: znak ogólny dekompozycji, która w biedzie okropnej, gene- 
ralnej, koniecznie nastąpić musi. Nie poznaję moich najlepszych 'dawniejszych przyjaciół. Wszystko to wyleciało ze swego naturalnego kresu; jest do najwyższego stopnia zirytowane, podejrzliwe i zgłupiało w nieszczęściu. Ja zupełnie żyję oddzielony od tego wszystkiego. Pisząc historię, wszedłem, bo musiałem wejść, w stosunki z ludźmi, którzy rewolucję rządzili i zgubili - dawnymi nieprzyjaciółmi mymi ${ }^{13}$. Ci ludzie (licząc w to cała partię, która się w Paryżu znajduje) ${ }^{14}$, zachowali więcej zimnej krwi, taktu i sumienia jak rewolucjoniści. Oni jedni z całej emigracji nie kłócą się $z$ sobą i nie obmawiają nawzajem. Ja zostaję teraz z nimi w dobrej harmonii - bo potrzebuję od nich materiałów, co jednak żadnego wpływu na dzieło moje nie ma, bo ja pisze [wyraz nieczytelny]. Ze wszystkich moich dawniejszych przyjaciół został mi tylko jeden Nastuś ${ }^{15}$ i P[an] Michał ${ }^{16}$. Pierwszemu szkodzi i dokucza zła reputacja generała D.... ${ }^{17}$, 'szulera, marnotrawcy'; drugi jest tetryk ze słabości i wielkiego niedostatku. Donoszę tedy kochanemu Papie, że emigracja może być rozbita w skutku położenia, które opisałem, ale że to na mój los żadnego wpływu mieć nie może, bo nie masz kombinacji, w której bym mógł wrócić do kraju, jako należacy do kategorii skazanych na śmierć w Warszawie. Mnie nic innego nie pozostaje, tylko siedzieć w Paryżu, pracować i zarabiać sobie na życie i dobre imię u ludzi, i starać się, żeby kochany Papa, dla którego nie masz bezpieczeństwa w Galicji, połączył się ze mną. O moich interesach to jeszcze donoszę Papie: tom $1^{\mathrm{y}}$ i drugi, ,według życzenia Papy`, wyekspediuję drogą najpewniejszą, bez skompromitowania kochanego Papy. Za tom $3^{\mathrm{ci}}$ i $4^{\mathrm{y}}$ prenumeratorowie moi niech zapłaca drugie 15 fr[anków]. $Z$ tych pieniędzy ja ani jednego grosza nie potrzebuję. Wszystko, co tylko się zbierze, jest własnością kochanego Papy. Jest to święty fundusz na drogę dla Papy, na drogę, którą wpływ Moskwy w Austrii czyni konieczną i niezbędną. Ekspedycja tomów niezmiernie trudna, jest jednak podobna. Słabość moja wstrzymała postęp tomu $3^{\text {goo }}$; ledwo za dni 20 będę w stanie pracować. Riccord zakazuje mi zupełnie teraz sedenterii ${ }^{18}$ pod kara recydywy - ale zabrania także i wielkiego ruchu. Tak być musi czas niejaki.

Wiele razy dom nasz jakie nieszczęście spotyka, po tylekroć od młodości mojej spostrzegam około niego rękę przyjacielska kochanego i drogiego mojemu sercu Pana Jana Henryka ${ }^{19}$ ! On jeden zawsze tę naszą skołataną budowę podpiera w burzy i do reszty upaść jej nie dozwala. Jakże to pięknie z Jego strony, jak szlachetnie!! To, co mi Papa teraz o 'skreśl.’ nim piszesz, do łez mnie pobudziło... Zawsze ten sam - kochać go więcej nie mogę, jak go przedtem kochałem, ale uczę się w miarę nieszczęść naszych coraz lepiej poznawać Jego charakter i Jego cnoty!

Chwała Bogu, że Klementyna skończyła swoją karierę rozwódki ${ }^{20}$. Ale co się z jej dziećmi dzieje? ${ }^{21}$ Wracając się do Tymoleona, nie tyle żałuję straconego przytułku dla Mamy ${ }^{22}$, który nigdy nie mógł być serdeczny, skoro go taka drobnostka mogła odjać Mamie, ile że mogło przyjść do kolizji tego rodzaju. Jednak postępek Pani C.... ${ }^{23}$ jest zadziwiajacy. Nie zgadza się to wcale $z$ ową wysoką chrześcijańską cnota, o której kochana i dobra moja Mama tak wymownie ii często pisała, a za którą ja i Kamil nieboszczyk zasyłaliśmy dzięki niebu.

Wszakże można było wyperswadować pannie romanse, a nie wypowiadać schronienia matce tylu dzieci, osobie tak poważnej, dobrej i nieszczęśliwej wskutek powszechnego nieszczęścia - wreszcie krewnej, siostrze. Otóż tego ja wcale nie pojmuję! Lecz dom pod firmą O patrzności, jak się Mama wyraża w liście ${ }^{24}$, 
daleko dłużej będzie gościnnym dla Mamy jak Polanka - gdzie, widać, gościnność była tylko grzecznością chwilową dla oka, dla świata - gdzie wypatrywano tylko byle jakiej okazji pozbycia się ciężaru $\mathrm{z}$ domu.

Zaczynając ten list, miałem zamiar napisać go najobszerniej, ale to niepodobna. Dieta i pijawki tak mnie osłabiły, że już mi ręce drżą i nogi - i znowu do łóżka pójść muszę. Za to wolę, w miare jak mi zdrowie przybywać będzie, częściej odzywać się do kochanych Rodziców - teraz zaś uściskać tylko ich rączki i nóżki.

Maurycy

N.B. Wszystkie starania o wynalezienie listu Papy były daremne. Ponowię je, jak tylko zupełnie wyzdrowieję. I to jest także rzecz niewątpliwa, że ja pisałem parę listów, które Papa nie odebrał. Cóż bym miał za rację tak upornie przy tym obstawać? Pisałem te listy z ulicy Dauphine pod adresem zwyczajnym.

Adres mój jeszcze ten sam. Ale na zimę wyprowadzę się stąd i zaraz jak tylko się to stanie, doniosę o zmianie pomieszkania mojego.

\section{Maurycy}

Pojedyncza karta o wymiarach 21,0 × 25,7 cm, zapisana obustronnie w układzie dwukolumnowym. Pismo - zwłaszcza pod koniec listu - drobne, mniej staranne niż w poprzednim liście. Niektóre wyrazy trudne lub niemożliwe do odczytania. Rękopis zawiera skreślenia i liczne nadpisania, ponadto miejscami widać przebijający $z$ drugiej stronicy atrament. Brak koperty z informacją o odbiorcy.

1 Recydywa - tj. gwałtowny nawrót choroby.

2 Swoją 5-tygodniową chorobę Mochnacki szczegółowo opisał w liście do ojca z 28 VII 1833.

3 W pierwodruku: „Riccard”. Być może chodzi o Philippe’a Ri c o r d a (1800-1889), słynnego francuskiego fizyka i lekarza, autora takich prac z zakresu medycyny, jak: De l'emploi du spéculum (1833), De la blennorragie de la femme (1834), Monographie du chancre (1837), Théorie sur la nature et le traitement de l'épididymite (1838).

4 Medycyna - dawne określenie lekarstw, medykamentów.

5 Tymoleon Mochnacki wdał się wówczas w romans z córką Moniki Cieńskiej (dalekiej krewnej swojej matki), u której rodzina mieszkała po opuszczeniu Warszawy.

6 W przypisie do pierwodruku listu odnotowano: „Ciotka Maurycego, wdowa”. Szczegóły jej życia nie są znane.

7 Emigracja polska obawiała się, że Ludwik Filip I wykorzysta przyjazd Druckiego-Lubeckiego do Francji i usunie z kraju cudzoziemców. Drucki-Lubecki miał bowiem przybyć do Paryża nie tylko po to, by upomnieć się o zwrot pieniędzy wyłożonych przez Księstwo Warszawskie na armię francuską, ale również po to, by nakłonić polistopadowych emigrantów do przyjęcia amnestii.

8 Carlo Andrea Pozzo di Borgo (1764-1842), rosyjski polityk korsykańskiego pochodzenia, który w latach 1814-1835 pełnił funkcję ambasadora Rosji w Paryżu.

9 W pierwodruku: „Jarosławskiej”.

10 Chodzi o Druckiego-Lubeckiego.

11 Rząd francuski 21 IV 1832 uchwalił prawo, na mocy którego Ministerstwo Spraw Wewnętrznych wyznaczało emigrantom politycznym miejsce pobytu i mogło usunąc ich z kraju, gdyby nie przestrzegali obowiązujących zasad.

12 Sainte-Pélagie - słynne paryskie więzienie działające od 1790 roku.

13 W trakcie pisania historii powstania Mochnacki zbliżył się do środowiska księcia Adama Jerzego C zar t o ry s k i e go (1770-1861). W latach poprzednich razem z bratem Kamilem był zwolennikiem polityki generała Józefa Dwernicki e go (1779-1857).

14 Mowa o zwolennikach księcia Czartoryskiego, w późniejszym okresie skupionych wokół Hotelu Lambert. 
Tak Maurycy nazywał Anastazego D u n i n a (1802-1840), powstańca listopadowego zaprzyjaźnionego $\mathrm{z}$ rodzina Mochnackich.

16 Michał Podczaszyński.

17 Mowa o generale Dwernickim, stojącym na czele Komitetu Narodowego Emigracji Polskiej i skonfliktowanym wówczas z obozem popierającym księcia Czartoryskiego. To do niego był skierowany list „od oficerów, podoficerów i żołnierzy z zakładu w Auxerre” z 17 X 1834 autorstwa Mochnackiego. Dunin jako adiutant Dwernickiego popierał jego działalność polityczną.

Sedenteria (z łac.) - daw., siedzacy tryb życia.

19 Jan Henryk Sa ga tyń s ki (ok. 1760-1844), autor Pamiętników byłego pazia Stanisława Poniatowskiego, przy którym zostawał aż do śmierci (1845), przyjaciel rodziny Mochnackich. Nie wiadomo, o jakim wydarzeniu tutaj mowa.

20 Od roku 1823 mężem Klementyny był Maciej Grodziecki herbu Nałęcz (ok. 1808 - ?), major armii Królestwa Polskiego, oficer powstania listopadowego. W roku 1834 (30 IV) siostra Maurycego Mochnackiego ponownie wyszła za mąż - za Jana Filipa K u le s z ę herbu Ślepowron (1799-1872), znanego doktora medycyny i chirurgii.

21 Ze związku z Grodzieckim Klementyna Mochnacka miała dwójkę dzieci: Natalię Bronisławę (1827-1832) i Kamilę Klementynę (1831-1908). Później (z małżeństwa z Kuleszą) urodzili się Jan Władysław (1835-?), Ludwika Maria (1837-?) i Maurycy Wacław (1841-1859).

22 Maria Mochnacka na początku 1834 r. musiała zmienić miejsce zamieszkania. Z Polanki Wielkiej, gdzie dotąd przebywała, przeniosła się na jakiś czas do domu „pani Poniatowskiej” na Łyszakowie (dzisiaj: Łyczaków, dzielnica Lwowa). Przyczyną przeprowadzki był najprawdopodobniej romans Tymoleona $\mathrm{z}$ córką właścicielki domu.

23 Mowa o Monice Cieńskiej.

24 W komentarzu pod listem Maria Mochnacka zanotowała: „pisałam do Maurycego, że założyłam dom dla nas na nowo [u Poniatowskiej - A. M.] pod firma Boskiej Opatrzności, co memu kochanemu Maurycemu tak się podobało, że w tym liście swoim powtórzył [...]" (Listy Maurycego Mochnackiego i brata jego Kamila [...], s. 261-262).

\title{
Abstract \\ MOCHNACKI NEWLY REDISCOVERED TWO UNKNOWN HANDWRITTEN LETTERS
}

\author{
Edited by \\ AGNIESZKA MARKUSZEWSKA Nicolaus Copernicus University, Toruń \\ ORCID: 0000-0003-2511-4867
}

The analysis of a volume with Maurycy Mochnacki's and Kamil Mochnacki's letters to parents published in the year 1863, the first edition of the correspondence, reveals a number of editorial operations that serve the creation of the senders' images and discloses the $19^{\text {th }} \mathrm{c}$. characteristic strategies of composing "biographic portraits" in advance. In the volume in question, an important function is played by the numerous non-authorial deviations from the manuscript that deform the style and sense of the original account. They are most clearly visible in Maurycy Mochnacki's two letters dated July $25^{\text {th }}$, 1834 , and September $2^{\text {nd }}, 1834$, the manuscripts of which have only recently become the object of a detailed textological analysis. Since the handwritings of the two letters differ from the first edition to such an extent that they should be regarded as non-identical (over 100 differences), the handwritten versions are published here. Until this day, only the deformed letters were known and quoted. 